\title{
Bio Efficacy of Three Gravid Female Trichogramma chilonis against Important Lepidopteran Pests under Laboratory Condition
}

\author{
Honnayya* and R.W. Gawande \\ Entomology Section, College of Agriculture, Nagpur \\ Dr. Panjabrao Deshmukh Krishi Vidyapeeth, Krishinagar, Akola - 444104 \\ *Corresponding author
}

\section{A B S T R A C T}

\section{Keywords}

Gravid female, Lepidopteran pests, Trichogramma chilonis and Kharif

Article Info

Accepted:

06 June 2018

Available Online:

10 July 2018
The present study was conducted for efficient parasitization and efficacy of the three gravid female of Trichogramma chilonis (Ishii) against important lepidopteran pests viz., $H$. armigera, E. vitella, P. demoleus, A. janata and C. cephalonica, having 24, 48, and 72 hrs old age eggs were exposed to three gravid females of Trichogramma chilonis. Laboratory experiments were carried out at the college of Agriculture, Nagpur and CICR, Nagpur, Maharashtra during Kharif 2015. The results revealed that, the T. chilonis exhibited $86.25 \%$ parasitization on $24 \mathrm{hrs}$ old eggs of Helicoverpa armigera, 30.75 average number of adult emergence of $T$. chilonis in $24 \mathrm{hrs}$ old eggs of Papilio demoleus and 8.50 days required for adult emergence of $T$. chilonis in $72 \mathrm{hrs}$ old eggs of Papilio demoleus. It is concluded that percent parasitization was more in $H$. armigera and average number of adult emergence and days required for adult emergence was more in Papilio demoleus as compare to all the 5 treatments. Hence, the H. armigera and Papilio demoleus eggs was more suitable for rearing of parasitoid to get good development of biological parameters of T. chilonis.

\section{Introduction}

Biological control is an essential component in integrated pest management programs and often recommended as the first defence line to face the menace of economic pests. The hymenopteran parasitoid, Trichogramma chilonis (Ishii) (Hymenoptera: Trichogrammatidae) is considered as important biological control agent of insects pests in greenhouse and field crops. Male yellow with blackish abdomen and mesosculum, antennal hairs somewhat sharply tapering and moderately long, forewing with four to six oblique lines setae, fringe on torn us about one sixth width of wing. Genitalia with dorsal expansion of gynobasic triangular, with lateral lobes very prominent, chelate structure markedly below level of gonophores, median chitinized ridge paired, extending interiorly to about two- third length of genitalia, aedeagus as long as apodemes, both slightly shorter than hind tibia. And female yellow with first three abdominal terga black 
antennae clubbed with short hairs on flagellum, ovipositor as long as or slightly longer than hind tibiae (Albo 1986).

These Trichogramma can be integrated with the other control measures and mass reared cheaply and conveniently in the laboratory on unnatural hosts. These Trichogrammatids have over 203 genera and used against more than 200 insect species belonging to 70 families and 8 insect orders in diversified habits, mostly on the lepidopteran pests of different crops. It is necessary to adopt biological method, as one of the components of IPM for managing the above lepidopteran pests, since biological method is eco friendly, non-toxic to human. Moreover bio agent are host specific and have high searching and dispersal ability and having no residual effect. Though several inundative releases are required to suppress the population of the pests, but once the bio agent is established in a particular area sustainable suppression of pest are achieved by this method.

There are several bio agents used to control the pests. The Trichogramma chilonis is an alternative bio agent that has been found to be effective against lepidopteran pests. The bio efficacy of Trichogramma has been tested against some lepidopteron pests. $T$. chilonis (Ishii) is most suitable egg parasitoid for controlling the lepidopteron pests (Singh and Jalali, 1994). These Trichogramma parasitize the eggs thus killing the lepidopteron pests before they could inflict damage to the host plant i.e. 'Nip at the bud' strategy. The use of bio agent reduces the chemical spraying ultimately conserve the natural enemies of pests. These tiny wasps have wide range and adoptability, host specificity, safety to use, cheap availability and inhibits almost all kinds of habitats from swampy marshland to hot dry deserts and occurs in low-laying or in strictly arboreal habitats (Sudha nagarakatti and Nagaraja, 1977)
In India about 26 species ofTrichogrammatids are recorded of which $T$. chilonis (Ishii), $T$. japonicum Ashmead, T. achaeae Nagaraja and Nagarkatti are most suitable egg parasitoids for managing the lepidopteran pests (Singh and Jalali, 1994). Parasitoid release and insecticidal application at a time cannot work together, hence, it is imperative to conserve the natural enemies in agro- ecosystem by avoiding the use of deleterious insecticides. However, more study regarding agepreference of host egg needs to be investigated against different major lepidopteran pests on commercially important crops.

Trichogrammatids are one of the most important groups of biotic agent for the suppression of several lepidopteron pests all over India and widely distributed species of egg parasitoid in India and abroad. Over 200 insect species are parasitized by various strains of Trichogrammatids. Out of 26 Trichogramma species recorded in India, $T$. Chilnis, T. Japonicum, T. Acheae, are key mortality factors for many crop pest.

Ever since 1975, Trichogramma are being used to control lepidopterous pests of cotton, cabbage, apple and tomato etc. (Smith, 1996). The quality parasitoids can be produced by studying biological features of Trichogramma adult as longevity, emergence and parasitism abilities (Bigler, 1991). To get high rate of emergence in laboratory in hot summer, artificial manipulation in temperature is necessary for successful rearing (Rejendran, 1999). The chemical control not only increases the cost of production but also is dangerous for the health of farmers and for environment. One of the safe measures to evade such a situation is biological control. It is an alternate or an adjunct to chemical control, and has successfully been used to control many pests including cotton bollworms (Cock, 1985). 
Trichogramma chilonis (Ishii), for the control of lepidopterous pests is practiced in more than 50 countries and used on 32 million hectares each year (Hassan, 1993). Trichogramma spp. has the great potential to control bollworms in cotton IPM (Verma and Shenhmar, 1998). The Trichogramma are hymenopterous parasitoids of lepidopterous insect pests (Cadapan and Gonzales, 1986). They are minute $(0.1-0.5 \mathrm{~mm})$ endoparasitic insects which prey on other insects eggs. They complete their life cycle inside the eggs of other insects and kill the host before it is hatched. They belong to the chalcid group of hymenopterous insects in the family Trichogrammatidae (Cadapan, 1986).

\section{Materials and Methods}

\section{Details of experiment}

1) Test parasitoid: Trichogramma chilonis

2) Experimental Designs: Completely Randomized Design (CRD)

3) No. of replications:4

4) No. of treatments: 5

\section{Treatments}

$\begin{array}{lll}\mathrm{T}_{1} & - & \text { Helicoverpa armigera } \\ \mathrm{T}_{2} & - & \text { Earias vitella } \\ \mathrm{T}_{3} & - & \text { Papilio demoleus } \\ \mathrm{T}_{4} & - & \text { Achoea janata } \\ \mathrm{T}_{5} & - & \text { Corcyra cephalonica }\end{array}$

\section{Procedure for test}

\section{Rearing of larvae of lepidopteran pests}

Larvae of lepidopteran pests (H. armigera, $E$. vitella, $P$. demoleus, $A$. janata and $C$. cephalonica) were collected from different host plants and were reared in plastic containers by providing the natural diet till the pupal stage under laboratory condition. The pupae of lepidopteran pests were obtained and were kept in large size plastic jars and emerged adults were transferred into oviposition chamber for mating and oviposition.

Adult of lepidopteran pests were released into oviposition chamber by providing $40 \%$ honey diet in hanging cotton swab, folded centaury paper for oviposition. Upper opening of ovipositon chamber was closed with muslin cloth fixed with rubber band. All these materials were disinfected by using Sodium hypochloride $0.05 \%$ before the experiment.

\section{Exposure of host eggs to gravid female of Trichogramma chilonis}

Eggs of all host viz., $H$. armigera, E. vitella, $P$. demoleus, $A$. janata and $C$. cephalonica having 24, 48, and $72 \mathrm{hrs}$ old age were exposed to three gravid females of Trichogramma chilonis. Twenty eggs of each host were exposed to the parasitoid. The same set was replicated four times. The desired size empty cards were smeared with gum and required quantity of eggs i.e. twenty eggs on each cards were sticked on them. These cards were kept in test tubes. For identification of females of Trichogramma chilonis. Strip of untreated Corcyra eggs were placed in test tube in which a strip of parasitized tricho cards was inserted.

The adults of Trichogramma chilonis which emerged out from the eggs were observed. The females after mating and lapse of waiting period were attracted towards the eggs of Corcyra for oviposition, such females were picked up with fine camel brush and three female were placed into each test tube containing the lepidopteran pest's eggs. In this way lepidopteran eggs were exposed to three gravid female of Trichogramma chilonis under laboratory condition. The following observations were recorded. 


\section{The following observations were recorded}

i) Per cent egg parasitisation

ii)Number of days required for adult emergence

iii) Number of parasitoids emerged

\section{Statistical analysis}

The data of all sets of experiment were collected scrupulously through observation (compiled, average tabulated). The tabulated data after appropriate transformations were subjected to statistical analysis as per Gomez and Gomez (1984).

\section{Results and Discussion}

\section{Screening of Trichogrammatids}

Results obtained with regards to the per cent parasitization, average number of parasitoids emerged and average number of days required for adult emergence of Trichogramma chilonis., in the laboratory on important lepidopteran pests (Helicoverpa armigera, Earias vitella, Papilio demoleus, A. janata and Corcyra cephalonica) has been presented.

Effect of three gravid female Trichogramma chilonis on important lepidopteran pests

A) Per cent eggs parasitization by Trichogramma chilonis

The data presented in the (Table 1). revealed that, the age of the host eggs, significantly influenced the parasitization by Trichogramma chilonis.

The data showed that, the maximum amount of parasitization was recorded in $24 \mathrm{hrs}$ old eggs and followed by $48 \mathrm{hrs}$ and $72 \mathrm{hrs}$ old eggs, the lowest parasitization was observed in 72 hrs old eggs.
The maximum per cent parasitization was recorded by Trichogramma chilonis on $24 \mathrm{hrs}$ old eggs of Helicoverpa armigera (86.25\%) and followed by Corcyra cephalonica (83.75\%), Papilio demoleus (81.25\%), Earias vitella $(78.75 \%)$ and Achoea janata (71.25\%) respectively. The highest per cent parasitization was recorded on Helicoverpa armigera $(86.25 \%)$, however, the treatment Corcyra cephalonica (83.75\%), found statistically on par with Helicoverpa armigera (86.25\%). The treatments Papilio demoleus $(81.25 \%)$, found second best in egg parasitization. The host treatments Earias vitella $(78.75 \%)$ and Achoea janata (71.25\%) shown parity with each other in per cent egg parasitization.

After an exposure period of $48 \mathrm{hrs}$ old eggs, the results showed similar trend like $24 \mathrm{hrs}$ exposure with highest per cent parasitization observed in Helicoverpa armigera eggs $(83.75 \%)$ and followed by Corcyra cephalonica (81.25\%), Papilio demoleus (78.75\%), Earias vitella (73.75\%) and Achoea janata $(66.25 \%)$ respectively. However, the per cent parasitization recorded in the treatment Corcyra cephalonica (81.25\%), Papilio demoleus (78.75), and Earias vitella (73.75) were statistically on par with the Helicoverpa armigera (83.75\%). The host treatment Achoea janata (66.25\%) shown least preference in per cent egg parasitization, amongst other hosts.

The parasitization by Trichogramma chilonis against important lepidopteran pests exhibited decreasing trend on $72 \mathrm{hrs}$ old eggs, exposure period in per cent parasitization as compared to $24 \mathrm{hrs}$ in all treatments Viz., Helicoverpa armigera $(78.75 \%)$ and followed by Corcyra cephalonica (75.00\%), Papilio demoleus (72.50\%), Earias vitella (70.00\%) and Achoea janata $(63.75 \%)$ respectively. However, the parasitization recorded in the treatment Corcyra cephalonica (75.00\%) and Papilio 
demoleus $(72.50 \%)$ were found statistically on par with Helicoverpa armigera $(78.75 \%)$. The host treatments Earias vitella $(70.00 \%)$ and Achoea janata $(63.75 \%)$ shown parity with each other in egg parasitization.

Present study indicated that, the maximum parasitization was noticed in $24 \mathrm{hrs}$ old eggs of Helicoverpa armigera (86.25\%) and followed by $48 \mathrm{hrs}$ and $72 \mathrm{hrs}$ old eggs and lowest parasitization was recorded in Achoea janata $(63.75 \%)$ in 72 hrs old eggs. The reason being Trichogrammachilonis mainly preferred freshly laid eggs for parasitization.

These results are comparable with the findings of earlier studies made by Kumar Arvind and Khan (2012) who evaluated for the parasitization of Trichogramma chilonis in the host eggs of H.armigera showed highest percent of egg parasitisation $83.75 \%$ in laboratory. Thus these findings gave supports to present investigation.

Budhawant et al., (2008) who have found that, maximum per cent parasitization was recorded in fresh eggs (24 hrs old) of Helicovrpa armigera $(65.1 \%)$ were most preferred by Trichogramma chilonis. Thus these findings gave supports to present investigation.

\section{B) Average number of parasitoids emergence}

The statistical data on average number of parasitoids emergence presented in (Table 2). Revealed that, the development (egg to adult emergence) of Trichogramma chilonis among the different age groups of host eggs was significantly found more in $24 \mathrm{hrs}$ old eggs.

The findings on adult emergence by feeding $24 \mathrm{hrs}$ old eggs, revealed that, the treatment Papilio demoleus exhibited maximum adult emergence to the tune of 30.75 adult emerged.
However, the treatments Helicoverpa armigera (27.50) and Corcyra cephalonica (25.75) were found on par with Papilio demoleus (30.75) in adult emergence. The treatment Earias vitella was found second best in which (25.00) adult emerged. The treatment Achoea janata (23.50) was found on par with treatment Earias vitella (25.00) in adult emergence.

The observations on exposure period of $48 \mathrm{hrs}$ old eggs revealed that, the treatment Papilio demoleus exhibited maximum adult emergence to the tune of (27.50) number of adult emerged. However, the host treatment Helicoverpa armigera (26.25), Earias vitella (24.25), Achoea janata (23.00) and Corcyra cephalonica (25.00) were found on par with each other in adult emergence.

After an exposure period of $72 \mathrm{hrs}$ of old eggs, the treatment Papilio demoleus exhibited maximum adult emergence to the tune of (25.75) number of adult emerged. The treatment Helicoverpa armigerawas found second best in which 24.25 adult emerged. However, the treatments, Corcyra cephalonica (23.25), Achoea janata (22.75) and Earias vitella (23.00) were found on par with each other in adult emergence.

The data recorded on parasitoids emergence at $24 \mathrm{hrs}, 48 \mathrm{hrs}$ and $72 \mathrm{hrs}$ old eggs concluded that, the treatment Papilio demoleus was found superior in recording maximum parasitoid emergence ranging from 30.75, 27.50 and 25.75 adult emergences respectively.

The lowest number of adult emergence 23.00 was observed in Earias vitella, because the size of the host eggs was large, which was observed in Papilio demoleus and also age of the host egg increases the egg cell (chorion) becomes hard. 
Table.1 Effect of three gravid female Trichogramma chilonis on per cent egg parasitisation by Trichogramma chilonis

\begin{tabular}{|c|c|c|c|c|c|}
\hline \multirow{2}{*}{$\begin{array}{l}\text { Sl. } \\
\text { No. }\end{array}$} & \multirow[t]{2}{*}{ Treatment } & \multirow{2}{*}{$\begin{array}{l}\text { No of host } \\
\text { eggs } \\
\text { exposed }\end{array}$} & \multicolumn{3}{|c|}{ Mean per cent egg parasitization } \\
\hline & & & $\begin{array}{c}24 \text { hrs old } \\
\text { eggs }\end{array}$ & $\begin{array}{l}48 \text { hrs old } \\
\text { eggs }\end{array}$ & $\begin{array}{l}72 \text { hrs old } \\
\text { eggs }\end{array}$ \\
\hline 1 & T1-H. armigera & 20 & $\begin{array}{c}86.25 \\
(68.30)\end{array}$ & $\begin{array}{c}83.75 \\
(66.27)\end{array}$ & $\begin{array}{c}78.75 \\
(62.58)\end{array}$ \\
\hline 2 & T2- E. vitella & 20 & $\begin{array}{c}78.75 \\
(62.58)\end{array}$ & $\begin{array}{c}73.75 \\
(59.20)\end{array}$ & $\begin{array}{c}70.00 \\
(56.79)\end{array}$ \\
\hline 3 & T3-P. demoleus & 20 & $\begin{array}{c}81.25 \\
(64.38)\end{array}$ & $\begin{array}{c}78.75 \\
(62.58)\end{array}$ & $\begin{array}{c}72.50 \\
(58.39)\end{array}$ \\
\hline 4 & T4- A. Janata & 20 & $\begin{array}{c}71.25 \\
(57.59)\end{array}$ & $\begin{array}{c}66.25 \\
(54.49)\end{array}$ & $\begin{array}{c}63.75 \\
(52.99)\end{array}$ \\
\hline \multirow[t]{4}{*}{5} & $\begin{array}{l}\text { T5-C. } \\
\text { cephalonica }\end{array}$ & 20 & $\begin{array}{c}83.75 \\
(66.27)\end{array}$ & $\begin{array}{c}81.25 \\
(64.38)\end{array}$ & $\begin{array}{c}75.00 \\
(60.00)\end{array}$ \\
\hline & 'F' test & & Sig & Sig & Sig \\
\hline & $\mathrm{SE}(\mathrm{m}) \pm$ & & 0.93 & 0.87 & 0.65 \\
\hline & CD at $5 \%$ & & 2.75 & 2.59 & 1.92 \\
\hline
\end{tabular}

Table.2 Effect of three gravid female Trichogramma chilonis onaverage number of parasitoids emergence

\begin{tabular}{|c|c|c|c|c|c|}
\hline \multirow{2}{*}{$\begin{array}{l}\text { Sl. } \\
\text { No. }\end{array}$} & \multirow[t]{2}{*}{ Treatment } & \multirow{2}{*}{$\begin{array}{l}\text { No of host } \\
\text { eggs } \\
\text { exposed }\end{array}$} & \multicolumn{3}{|c|}{ Average number parasitoids emergence } \\
\hline & & & 24hrs old eggs & $\begin{array}{l}48 \text { hrs old } \\
\text { eggs }\end{array}$ & $\begin{array}{l}72 \text { hrs old } \\
\text { eggs }\end{array}$ \\
\hline 1 & T1-H. armigera & 20 & 27.50 & 26.25 & 24.25 \\
\hline 2 & T2- E. vitella & 20 & 25.00 & 24.25 & 23.00 \\
\hline 3 & T3- P. demoleus & 20 & 30.75 & 27.50 & 25.75 \\
\hline 4 & T4- A. Janata & 20 & 23.50 & 23.00 & 22.75 \\
\hline 5 & $\begin{array}{l}\text { T5-C. } \\
\text { cephalonica }\end{array}$ & 20 & 25.75 & 25.00 & 23.25 \\
\hline & ' $F$ ' test & & Sig & Sig & Sig \\
\hline & $\mathrm{SE}(\mathrm{m}) \pm$ & & 0.24 & 0.23 & 0.34 \\
\hline & CD at $5 \%$ & & 0.69 & 0.66 & 0.98 \\
\hline
\end{tabular}


Table.3 Effect of three gravid female Trichogramma chilonis onaverage number of days required for adult emergence

\begin{tabular}{|c|c|c|c|c|c|}
\hline \multirow{2}{*}{$\begin{array}{l}\text { S1. } \\
\text { No. }\end{array}$} & \multirow[t]{2}{*}{ Treatment } & \multirow{2}{*}{$\begin{array}{c}\text { No of host } \\
\text { eggs } \\
\text { exposed }\end{array}$} & \multicolumn{3}{|c|}{ Average number of days } \\
\hline & & & 24hrs old eggs & $\begin{array}{l}48 \text { hrs old } \\
\text { eggs }\end{array}$ & $\begin{array}{c}72 \text { hrs old } \\
\text { eggs }\end{array}$ \\
\hline 1 & $\mathrm{~T} 1-H$. armigera & 20 & 7.00 & 7.50 & 7.50 \\
\hline 2 & T2- E. vitella & 20 & 7.50 & 7.25 & 7.75 \\
\hline 3 & T3-P. demoleus & 20 & 8.00 & 8.25 & 8.50 \\
\hline 4 & T4- A. Janata & 20 & 7.25 & 8.00 & 8.25 \\
\hline 5 & $\begin{array}{l}\mathrm{T} 5-C . \\
\text { cephalonica }\end{array}$ & 20 & 7.50 & 7.25 & 7.25 \\
\hline & 'F' test & & NS & Sig & Sig \\
\hline & $\mathrm{SE}(\mathrm{m}) \pm$ & & 0.21 & 0.23 & 0.27 \\
\hline & $\mathrm{CD}$ at $5 \%$ & & 0.61 & 0.67 & 0.79 \\
\hline
\end{tabular}

These results are comparable with the findings of earlier studies made by Budhwant et al., (2008) who recorded maximum numbers i.e. 10.59 adults of $T$. chilonis were emerged out from $P$. demoleus host eggs. Thus these findings gave supports to present investigation. Thus these findings gave supports to present investigation. Thus these findings gave support to present investigation.

Sajid Nadeem et al., (2009) who recorded maximum per cent emergence of Trichogramma chilonis was noticed in host eggs of Helicoverpa armigera (98.0\%).Thus these findings gave support to present investigation.

\section{C) Average number of days (period) required for adult emergence}

The observations recorded and presented in (Table 3). on the time required for adult emergence at 24 hrs old eggs revealed that, the treatment Papilio demoleus (8.00 days) required maximum number of days and was found on par with treatments Earias vitella (7.50 days), Corcyra cephalonica (7.50 days), Achoea janata (7.25 days) and Helicoverpa armigera (7.00 days). The treatment Helicoverpa armigera took lowest period i.e. 7.00 days for adult emergence. After on exposure period of $48 \mathrm{hrs}$ old eggs, the observations recorded on the time required for adult emergence, the treatment Papilio demoleus (8.25 days) required maximum number of days and was found on par with treatment Achoea janata (8.00 days). The treatment Earias vitella took lowest period i.e. 7.25 days and was found on par with treatments Helicoverpa armigera (7.50 days) and Corcyra cephalonica (7.25 days).

The observations recorded on the time required for adult emergence at $72 \mathrm{hrs}$ old eggs revealed that, the treatment Papilio demoleus (8.50 days) required maximum number of days for adult emergence. However, the treatment Achoea janata (8.25 days) and Earias vitella (7.75 days) was found on par with the treatment Papilio demoleus (8.50 days). The treatment Corcyra cephalonica took lowest period i.e. 7.25 days and was found on par with treatment Helicoverpa armigera (7.50 days) for adult emergence. 
The study showed that, the maximum number of days (period) required for adult emergence of Trichogramma chilonis was observed in 72 hrs old eggs of $P$. demoleus (8.50 days) and lowest number of days required for adult emergence was recorded in Helicoverpa armigera (7.00 days)in 24 hrs old eggs.

These results are comparable with the findings of earlier studies made by Krishnamoorthy and Singh (2001) who reported that, the Trichogramma chilonis readily parasitized $24 \mathrm{hrs}$ and $48 \mathrm{hrs}$ old eggs of Papilio spp, and emergence period was completed in 8.3 days. Thus these findings gave supports to present investigation.

Dadmal and Nemade (2008) who reported that, Trichogramma species parasitized 100 per cent egg when a single egg of Papilio demoleus was exposed per female. However, decreased parasitizing trend was noticed with increased density of egg, emergence period was more in Trichogramma chilonis (8.3 days). Thus these findings gave supports to present investigation.

\section{References}

Albo. M. C. (1986). Biology of Trichogramma species and their effectiveness as biological control for sugarcane stem borer M.S. thesis. UPLB, college laguna.

Bigler, F., Cerutti. F. and Laing. J.(1991). First draft of criteria for quality control (product control) of Trichogramma. Proceed. 5th Workshop Global IOBC Working Group on Quality Control of Mass Reared Arthopods, March, 25-28, 1991. Wageningen, the Netherlands, pp. 200-201.

Budhwant, N. P., Dadmal, S. M., Nemade, P.W. and Patil, M. S.(2008). Efficacy of Trichogramma chilonis (Ishii) against lepidopteran pests and age of host eggs. Entomology Section, College of Agriculture, Dr. P.D.K.V., Akola, 444 104, India. Annals of Plant Protection Sciences Year: 2008, Volume: 16, Issue: 1

Cadapan, E. P and Gonzales, P. G.(1986). Trichogramma mass production procedure for the village level. A terminal report submitted to R. P. German Cotton Project. 18. pp.

Cock, M. K. W. (1985). The use of parasitoids for augmentative biological control of pests in the Peoples Republic of China. Bio control News and Information, 6: 213-24.

Dadmal. S. M. and Nemade,P.W.(2008). Evaluation of Trichogramma Spp. against Eggs of Papilio demoleus Linn. PKV Res. J. Vol. 32 (1).

Gomez, K. A. and Gomez, A. A.(1984). Statistical procedure for agricultural research pub. By John Wiley and sons, New York: 643-644.

Hassan, S. A.(1993). The mass rearing and utilization of Trichogramma to control lepidopterous pests: Achievements and outlook. Pestic. Sci.,37: 387-91.

Krishnamoorthy A, and Singh, S. P. (2001). Record of egg parasite, Trichogramma chilonis on Papilio spp. in citrus. CurrentScience India, 55(9): 461.

Kumar Arvind and M. A. Khan. (2012). Use of Trichogrammaspecies as potential biological control agents against sunflower head borer, Helicoverpa armigera (Hübner.) Forest Protection Division, Institute of Forest Productivity, Gumla Road NH -23, Lalgutwa, Ranchi-835 303, Jharkhand, India, Journal of Entomological Research, Volume: 36, Issue: 1.

Rajendran, B.(1999). Emergence of Trichogramma chilonis from the parasitoid cards under laboratory 
conditions during 1996-1998. Coop. Sugar, 31: 331.

Sajid Nadeem., Muhammad Ashfaq., Muhammad Hamed., Sohail Ahmed. and Muhammad Kashif Nadeem.(2009). Comparative rearing of Trichogramma chilonis (ishii) (hymenoptera: Trichogrammatidae) at different temperature conditions. Nuclear Institute for Agriculture and Biology (NIAB), Jhang Road, Faisalabad. Department of AgriEntomology, University of Agriculture, Faisalabad. Pak. Entomol. Vol. 31, No.1.

Sigh, S. P. and Jalali, S. K.(1994). Trichogrammatidae Technical Bull.
Project directorate of biological control, Benglore. 7; 93

Smith. S. M. (1996). Biological control with Trichogramma: Advances, success and potential of their use. Ann. Rev. Entomol. 41: 375-406.

Sudha Nagarkatti and Nagaraja, H.(1977). Bio systemic of Trichogramma and Trichogrammatoidae species. Annu. Rev. Entomol., 22: 157-176.

Verma. G. C and M. Shenhmar. (1988). Parasitoids of Pectinophora gossypiella (Saunders) (Lepidoptera: Gelechiidae) and Earias spp.(Lepidoptera: Noctuidae) in Punjab. J. Res., Punjab Agric. Univ., Ludhiana, India, 25: 592-4.

\section{How to cite this article:}

Honnayya and Gawande, R.W. 2018. Bio Efficacy of Three Gravid Female Trichogramma chilonis against Important Lepidopteran Pests Under Laboratory Condition. Int.J.Curr.Microbiol.App.Sci. 7(07): 571-579. doi: https://doi.org/10.20546/ijcmas.2018.707.070 